\section{Den centralasiatiske bog Nepal, Tibet, Bhutan og Mongoliet}

afforskningsbibliotekar Bent Lerbak Pedersen

U dviklingen af bogværker i det centralasiatiske område hænger på mange måder sammen med den buddhistiske lære. Samtidig med udbredelsen af buddhismen fra Nord-Indien over mod Kina blev bogformatet i Centralasien naturligt inspireret af det indiske traditionelle tværformat. Dette format kom fra brugen af palmeblade, der fra naturens hånd forekommer i lange smalle baner. Disse baner bliver lagt oven på hinanden og holdt sammen med snore igennem bladene og/eller med et svøb viklet om bladstakken.

Da papiret kom i anvendelse fra 1200-tallet, dels som erstatning for palmeblade og dels som supplement til dem, beholdt papiret palmebladsformatet. Dog udsattes dette format for en udvikling: typisk blev papirstykkerne kortere og bredere end palmebladene. Skriften var traditionelt skrevet fra venstre mod højre begyndende øverst på den lange side af bladene og i linier under hinanden.

I Centralasien ses tillige to traditionelle bogkulturer, der møder hinanden, nemlig den indiske og den kinesiske. I den indiske kultur var bogværker håndskrifter, mens bogværker i den kinesiske kultur mest var bloktrykte bøger. Bogtrykket blev opfundet i Kina allerede engang i 700-tallet og kom til at spille en vigtig rolle i det tibetan-

Fig. 1. Første blad i den buddhistiske tekst, Âryâstasâhasrikâyâh Prañâpâramitâyâh, i guldtusch på sortfarvet papir. Nederst ses en illustreret dakplade i tra og øverst ses varkets svøb. Dateret 1511 (Det Kongelige Bibliotek).

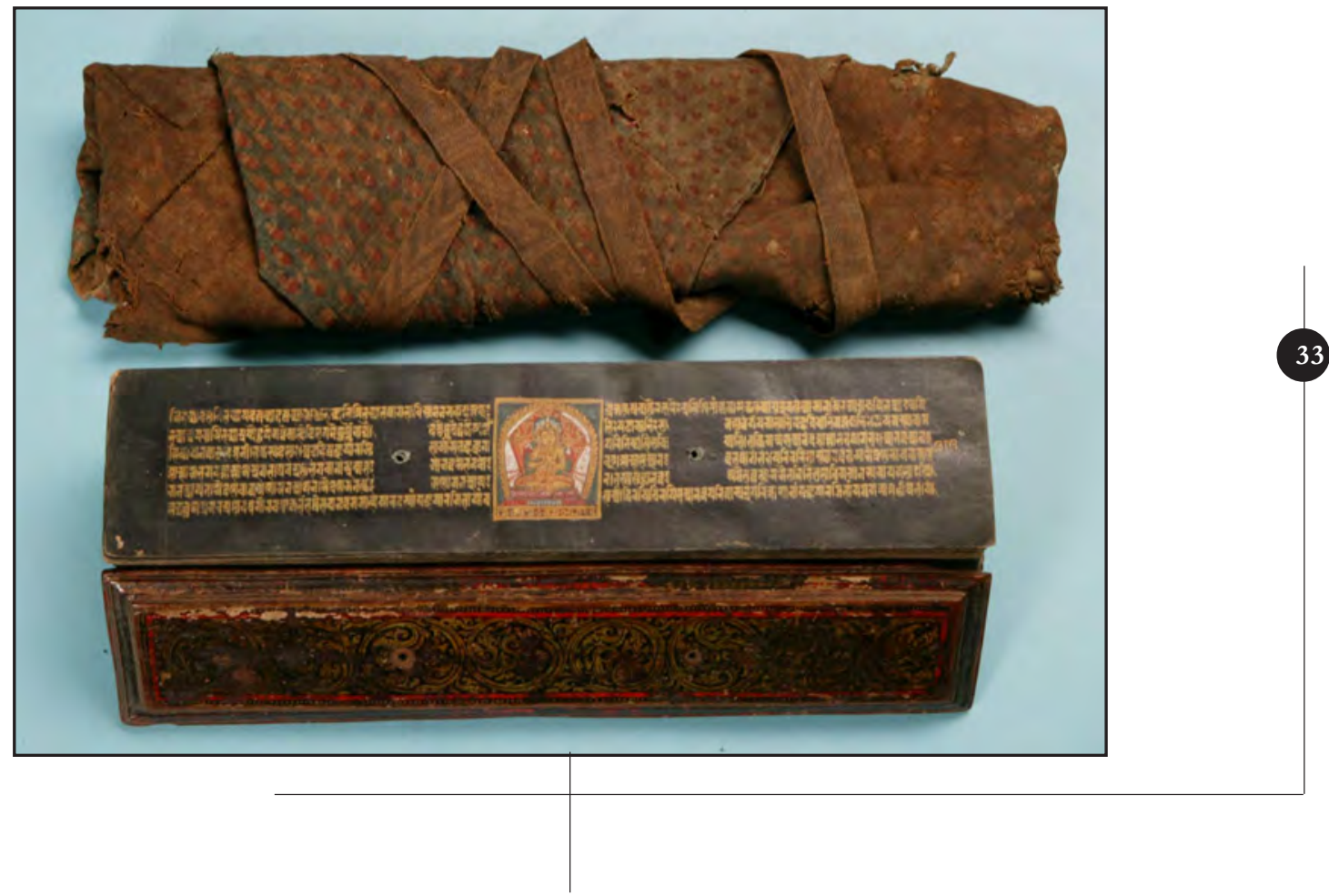


ske, bhutanske og mongolske område især fra 1500-tallet.

\section{Nepal}

$\mathrm{D}$ er er to hovedtyper af bøger i Nepal, dels palmebladsformatet og dels en kodekslignende bog med hæftet ryg. I den tidlige tid var det bark og importerede palmeblade, der var det mest almindelige skrivemateriale. Man skrev direkte på de forarbejdede bark- og palmeblade med tusch, og teksten blev placeret i pæn afstand fra kanterne og snorehullerne. Der blev skrevet på begge sider af bladene - først udfyldte man den ene side, så vendte man bladet og fortsatte at nedskrive teksten på bagsiden. På bark-og palmeblade skrev man med sort tusch. I en del håndskrifter er papiret farvet dybblåt eller sort, og på dem skrev man med guld- og sølvtusch. Teksterne var så skrevet i en af disse tuschfarver, men undertiden kunne sølv- og guldlinier dog veksle med hinanden.

Barkbladene er relativt korte, 20$25 \times 6 \mathrm{~cm}$, mens palmebladene er noget længere med en længde fra ca. 24 til $56 \mathrm{~cm}$ og en bredde på 4 til $7 \mathrm{~cm}$. Da papir blev taget $\mathrm{i}$ brug, kunne længden af papirblade ligeledes være meget varierende, lige fra korte, ca. $20 \mathrm{~cm}$, til ca. $40 \mathrm{~cm}$ lange. Der er to måder hvorpå papirbladene kan samles: de kan enten lægges som enkeltblade i en stabel, eller de kan limes sammen i en lang bane, der bliver foldet sammen som en harmonikabælg, kaldet en foldebog eller et leporello-album. Både palmebladsbøger og papirbøger i

Fig. 2. Buddhistiske hymner på sanskrit. Håndskrift på bark i palmebladsformat. Både dakpladen og siderne er afbark. Håndskrift fra 1400-tallet (Det Kongelige Bibliotek).

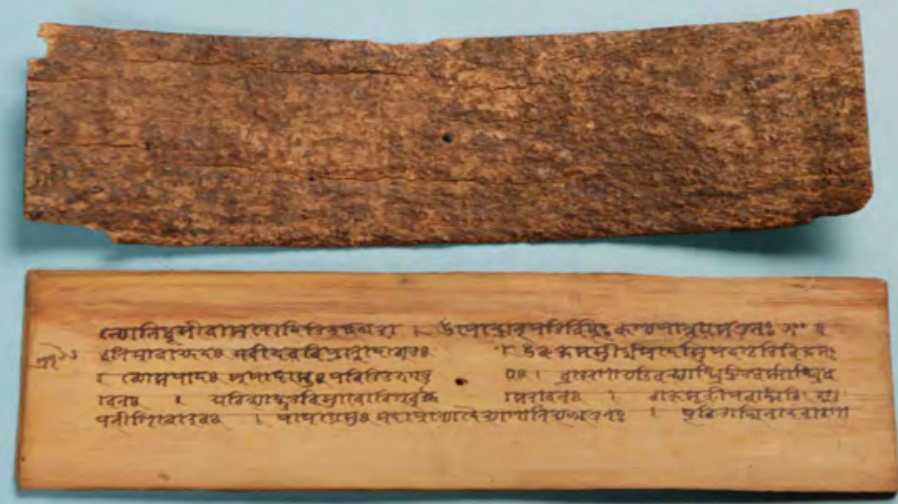




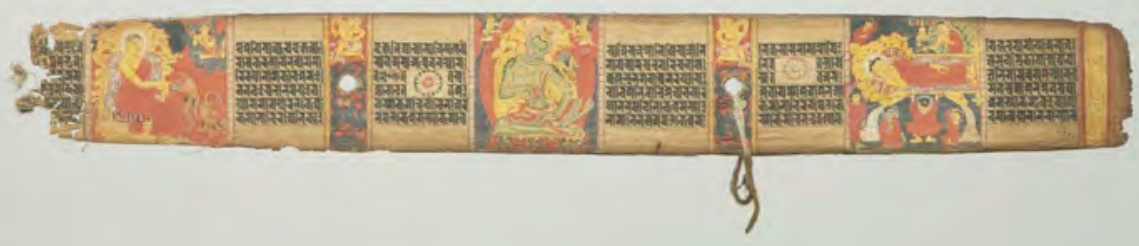

Fig. 3. Spalteopdelt buddhistisk tekst, Astasâhasrikâ-Prañâpâramitâ, på palmeblade. Teksten er placeret $i$ sektioner, der giver plads til smalle band ved snorehullerne og enderne afpalmebladene. Håndskrift fra 1100-tallet (Det Kongelige Bibliotek).

løsbladsform kan have huller til snore. Bark, palmeblade og papirblade blev ofte beskyttet af en øvre og nedre dækplade af træ.

Håndskrifter var for det meste uden illustrationer, men fra 1000-tallet begyndte man at male religiøse figurer på palmeblade. De er almindeligvis anbragt i midten af bladene, men på nogle er der desuden tilføjet to andre, som så er placeret på hver side af den midterste illustration. Teksten er anbragt i blokke uden om disse dekorationer. Nogle håndskrifter har dekorative bånd yderst på bladene med geometriske eller plantemønstre, gerne i rankeform. Sådanne dekorative bånd kan senere ses uden om en illustration. Illustrationerne males i farve på en grundet flade, så de står tydeligt frem. På palmeblade lægges illustrationerne fra kant til kant, men senere kan de på papirblade anbringes i felter i selve teksten, som en slags ruder.

De fleste illustrationer findes på de første blade i et håndskrift. Det drejer sig som regel om hellige figurer, og de placeres enten som enkeltfigurer eller som deltagere i fortællende episoder fra vigtige begivenheder i den pågældende religion. En illustration på første beskrevne blad får dette blad til at fremstå som et slags titelblad, der ellers ikke er særligt markeret i håndskrifter uden illustrationer.
I Nepal ser man både buddhistiske og hinduistiske håndskrifter, men de buddhistiske er dog de hyppigst forekommende. Der er ingen forskel på anbringelsen af malerierne hvad enten de kommer fra buddhismen eller hinduismen. De fleste illustrationer har ingen egentlig relation til håndskriftets tekst, de er mere anbragt som beskyttere af teksten og som givere af god karma. Det var velanset at donere fine håndskrifter til et tempel eller en brahman, hvorved giveren fremførte en god religiøs handling. Dette har formodentlig medført at håndskrifter blev fremstillet helt ind i 1900tallet.

Dækpladerne er for det meste illustreret med bemaling, men udskårne ydre sider ses ind imellem. Ydersiderne er sædvanligvis besmykket med geometriske mønstre og plantemønstre, mens indersiderne har fine billeder. Ligesom på selve arkene i håndskrifterne kan illustrationer være hele fortællinger eller være en række af religiøse figurer i egne afgrænsede kartoucher. Nogle fortællinger har et dekorativt bånd som adskillelse mellem de enkelte dele. Op til 1400-tallet er illustrationerne fint udført med mange livlige og detaljerede elementer, mens de senere illustrationer er mere enkle og undertiden noget naive i udførelsen. Med tiden er der ligeledes færre af dem. I de 


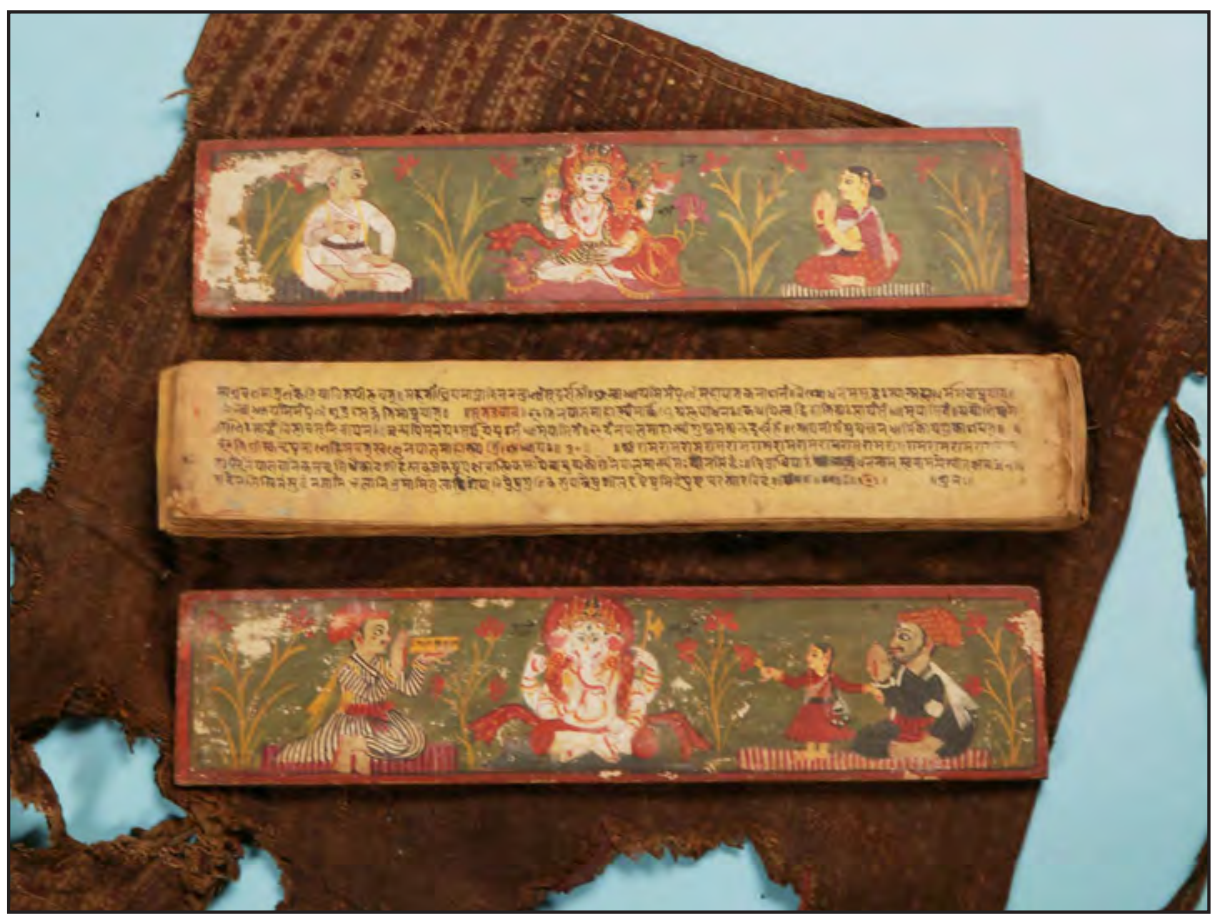

Fig. 4. De indre dekorerede dakplader med gudebilleder og forste blad af et sanskrit håndskrift fra 1753 med uddrag af Shadapurana/Nepala-Mahatmyra (krøniker fra 800-tallet om hellige steder og guddomme i Nepal) (Det Kongelige Bibliotek).

senere illustrerede dækplader kan man se tekstdele sammen med billederne, hvilket hænger sammen med udbredelsen af papir som grundlag for selve teksterne, hvor man netop kan se illustrationer og tekst på samme blad.

De fleste palmebladsbøger bliver holdt sammen af snore, der trækkes gennem to sæt huller, men en del håndskrifter har fået snorene erstattet af jernnagler, der også går igennem dækpladerne. For yderligere at beskytte håndskrifterne er de ofte viklet ind i et svøb. Disse svøb er gerne farverige med og uden geometriske og planteinspirerede tekstilmønstre. Svøbene holdes sammen af bændler, der tit er syet fast på svøbet.

I Nepal ses tillige foruden palmebladsformen en bogtype, hvor de enkelte blade er blevet syet sammen. Dette kan kun gøres med papir: man lagde de enkelte blade ovenpå hinanden, foldede dem sammen, hvorefter man hæftede dem sammen med en tråd gennem folden. Det kunne både gøres med få ark og med mange ark med mere end hundrede sider. Uden om denne hæftede bogblok anbragte man ofte et dække, som kunne være fremstillet af papir, skind eller papir omvundet med tekstil. Sådanne bind blev hæftet til bogblokken.

Teksten på disse kodekslignende bøger kunne skrives som i palmebladsformatet, hvor linierne følger øverste lange kant til den midterste fold ved hæftningen, således at teksten står i 90 grader til midten 


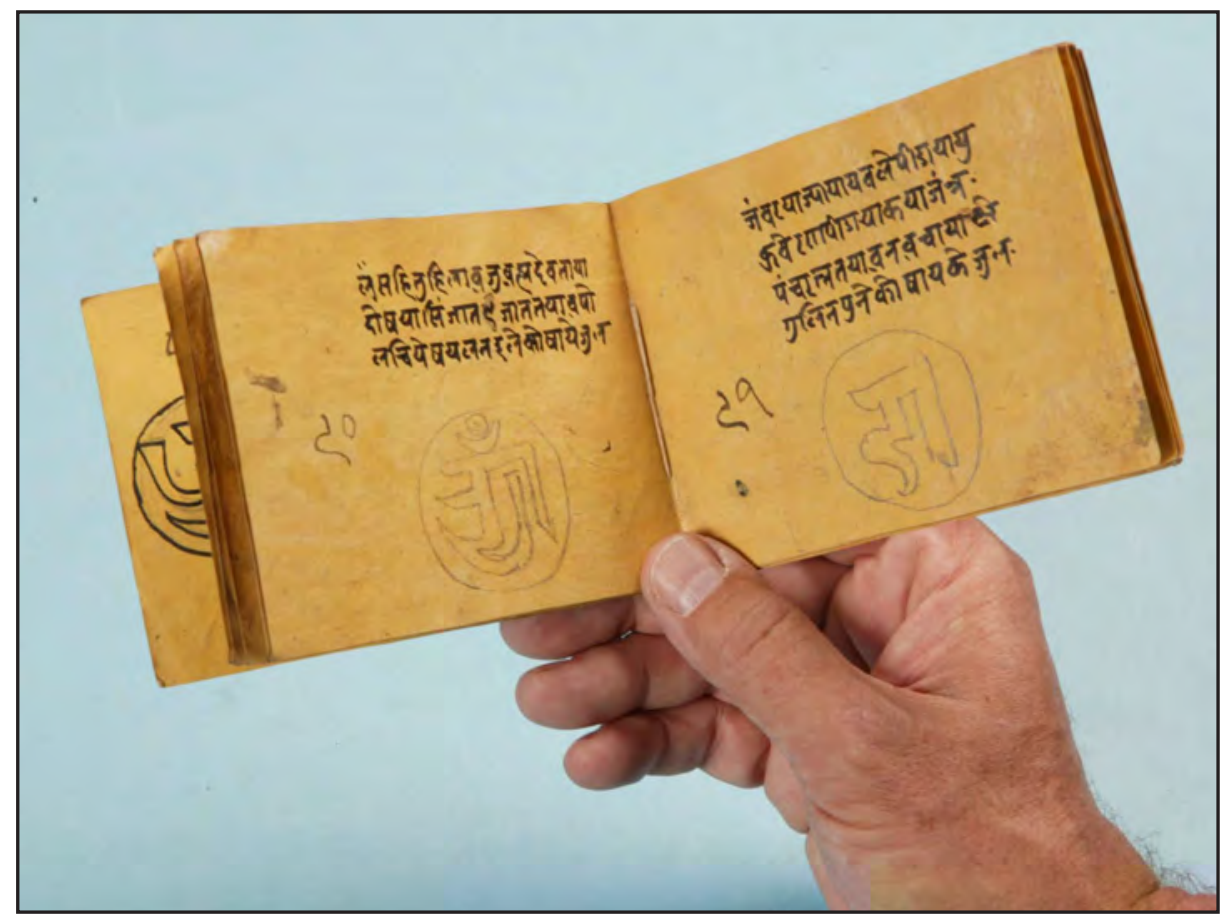

Fig. 5. Enkel haftning i et nepalesisk håndskrift. Forklaringer på nevârî om „kraftcentre“ i verden. 1800tallet (Det Kongelige Bibliotek).

ligesom på en vesterlandsk bog. Man kan også skrive teksten langs den smalle kant, dvs. dreje siderne 90 grader, således at tekstens linier ligger parallelt med folden og hæftningen. Dette kan minde om den vestlige notesblok, hvor siderne er limet på den smalle side og man kan vende siderne op og bag om de forrige blade.

Disse håndskrifter kunne ligeledes blive illustreret, og som oftest drejer det sig om små billeder, der er anbragt i selve teksten. Ligesom i Indien kan teksten blive indrammet af bånd i mere eller mindre dekorativ udførelse. Bindene på de hæftede bøger er som regel uden dekoration, men hvor man har lagt et stykke stof uden om bindet, ser man gerne enkle geometriske mønstre eller plantemønstre trykt på stoffet.
Moderne nepalesiske bøger trykkes, hæftes og indbindes oftest som vesterlandske. Buddhistiske værker kan dog udgives som trykte værker i det aflange tværformat.

\section{Tibet og Bhutan}

$\mathrm{D}$ a Bhutan overtog den lamaistiske buddhisme fra Tibet tidligt, er udformningen og udviklingen af den tibetanske og bhutanske bog ens.

De tidligste tibetanske håndskrifter, man kender, stammer fra den første del af 700-tallet. Det er ca. et hundrede år efter indførelsen af den tibetanske skrift. De er udført på papir i palmebladsformatet, og dette format er det mest udbredte i Tibet og Bhutan. Papiret i tibetanske og bhutanske 


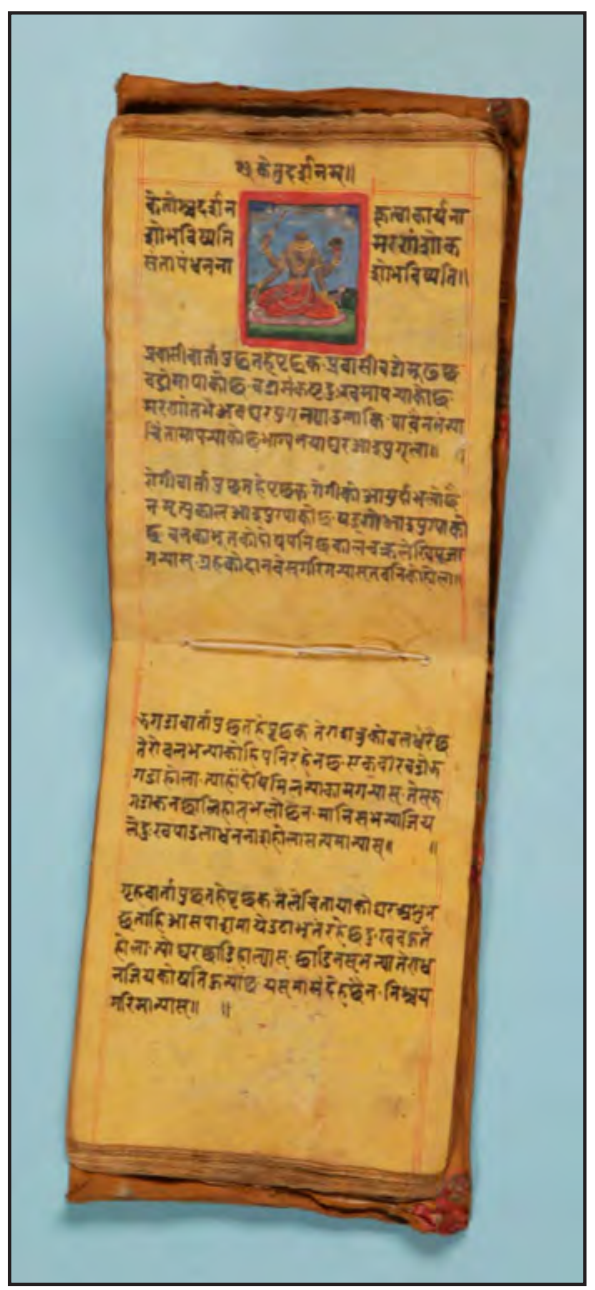

Fig. 6. Flerbladet bog i den enkle hafte-losning.

Nepalesisk håndskrift i sanskrit og nepalî til drømmetydninger med tekst integrerede illustrationer (Det Kongelige Bibliotek).

bøger var ofte lokalt produceret, men import fra Kina fandt også sted. Teksten er skrevet ligesom på palmeblade $\mathrm{i}$ linier langs den øvre lange kant fra venstre mod højre. Sædvanligvis er papirarkene samlet i stabler, men sammenlimede store papirark kan rulles op ligesom kinesiske håndskriftsruller. Det er yderst sjældent at tibetanske og bhutanske håndskrifter har huller til snore, da eventuelle snore let vil beskadige det tynde papir man sædvanligvis anvendte. Dog ser man cirkler tegnet hvor snorehullerne skulle have været anbragt. Papir benyttet til håndskrevne bøger er sædvanligvis af en kraftigere kvalitet end det papir, der anvendes til trykte tekster.

Bøgerne starter med et egentlig titelblad, der kan være enkelt udført med en enkelt linie, gerne i en firkantet ramme, eller der kan være flere tekstlinier undertiden på to eller tre sprog, dvs. som regel tibetansk og sanskrit, evt. suppleret med mongolsk eller manchurisk. Disse tekstlinier kan være indrammet i enkle rammer eller de kan være fint udsmykket. På ufarvet papir ser man sort undertiden suppleret med rød tusch, mens man på blåt eller sortfarvet papir ser guld- eller sølvtusch, som regel indrammet af røde linier. De fint dekorerede titelblade har almindeligvis bladet delt op i et til tre paneler. I centrum ses selve titlen og uden om dette er der lagt geometriske mønstre eller buddhistiske symbolmønstre. I særlig fine tilfælde ses to illustrationer uden om titelteksten udført som små miniaturemalerier med buddhistiske figurer. Sådanne fint udformede titelblade har fået anbragt et klæde hen over titlen og illustrationer som beskyttelse. Klædet er hæftet over dem og fungerer som et gardin. Gardinerne består af et eller flere stykker klæde, og de kunne være ensfarvede eller have plantelignende mønstre. I nogle tilfælde består gardinet af mere end et stykke klæde.

Den første side i teksten kan yderligere være illustreret med buddhistiske figurer, der enten er anbragt i midten eller for hver ende af arket. Dette ser man især udbredt hos de trykte tekster. Tibetanerne hentede inspiration hos kineserne i udbredelsen af deres buddhistiske tekster. Kine- 


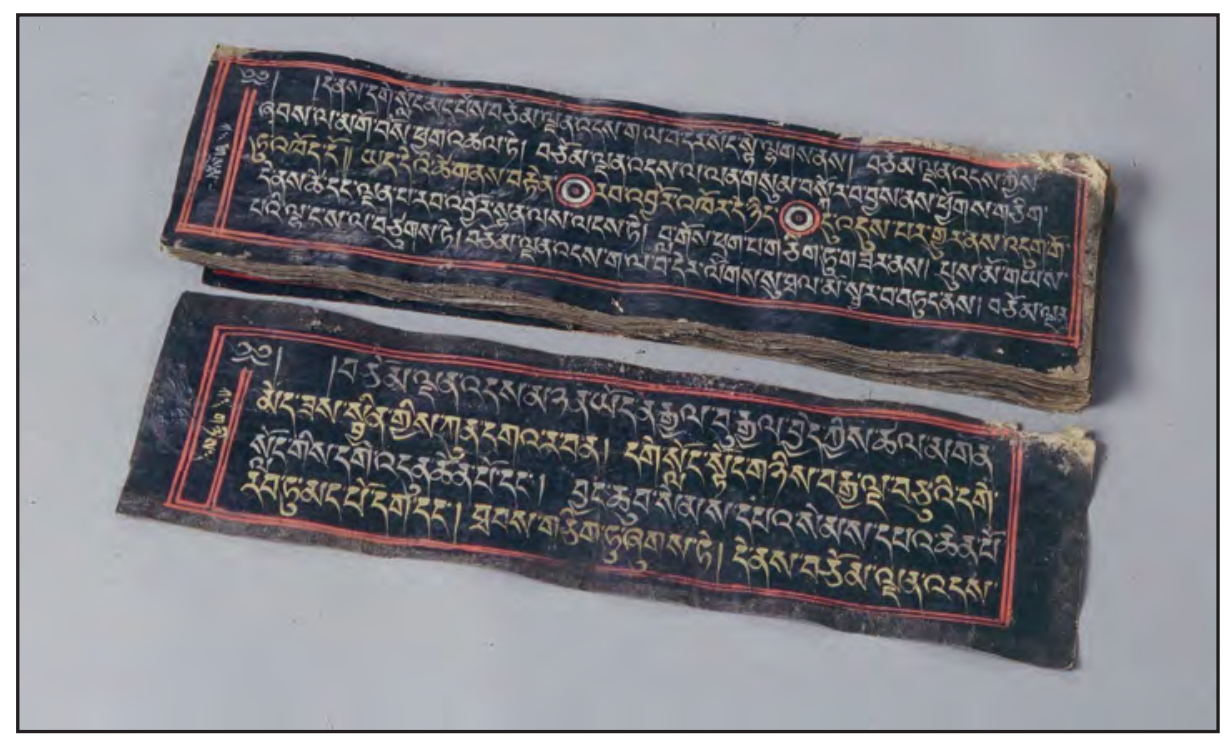

Fig. 7a. Tibetansk håndskrift i guld og sølv på blålakerede papirblade med Diamant-sutraen, som gengiver den mening, at alt hvad der findes, er illusioner opstået $i$ ens sind. Øverst ses tydelige markeringer af traditionelle snorehuller, der ikke skulle anvendes i dette skrift. Tidligt 1800-tal (Det Kongelige Biblitoek).

Fig. 7b. Samme Diamant-sutra-håndskrift som vist i fig. 7a. Her ses titelbladet med tilhørende beskyttelsesgardin og forste blad. Tidligt 1800-tal (Det Kongelige Bibliotek).

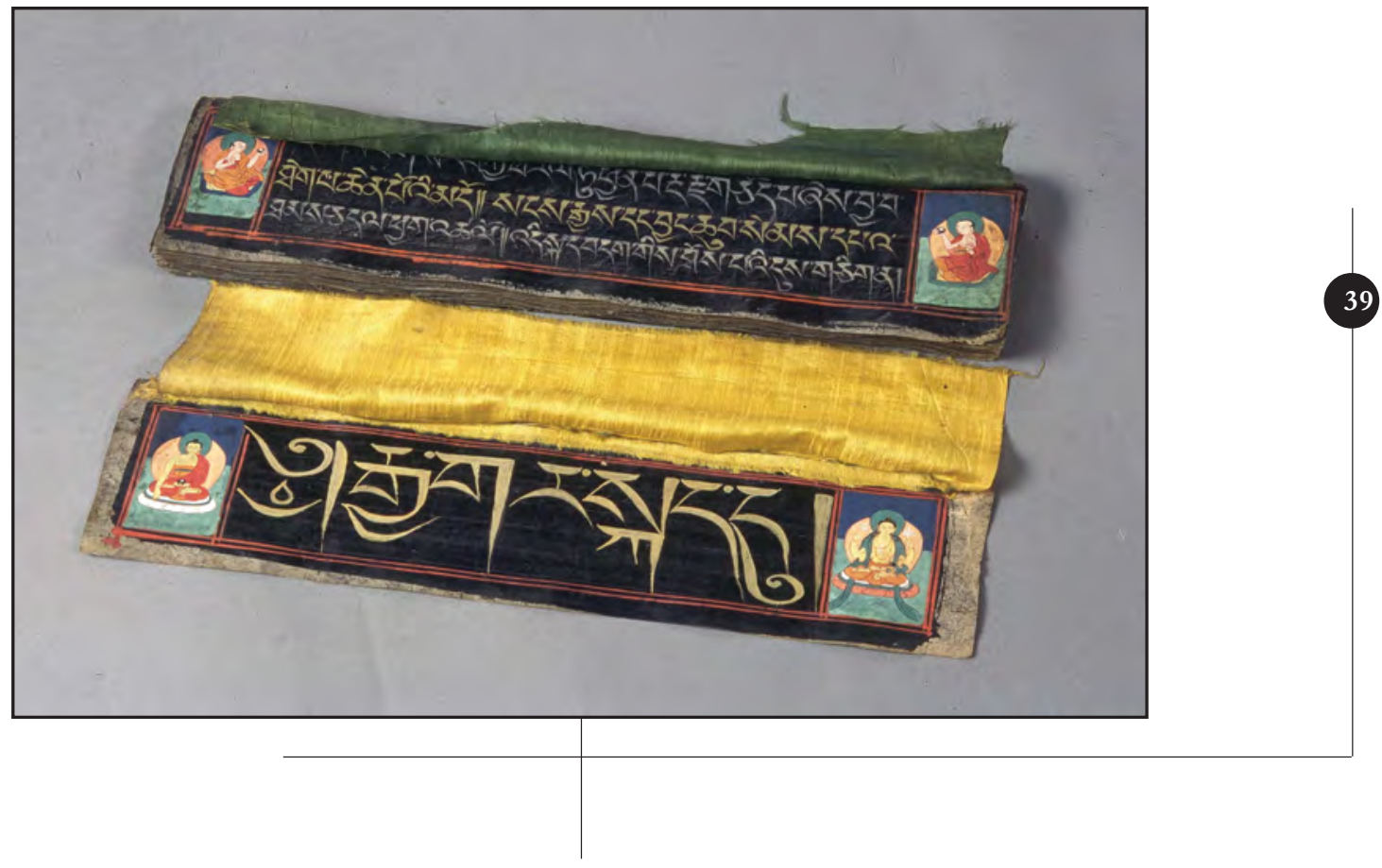




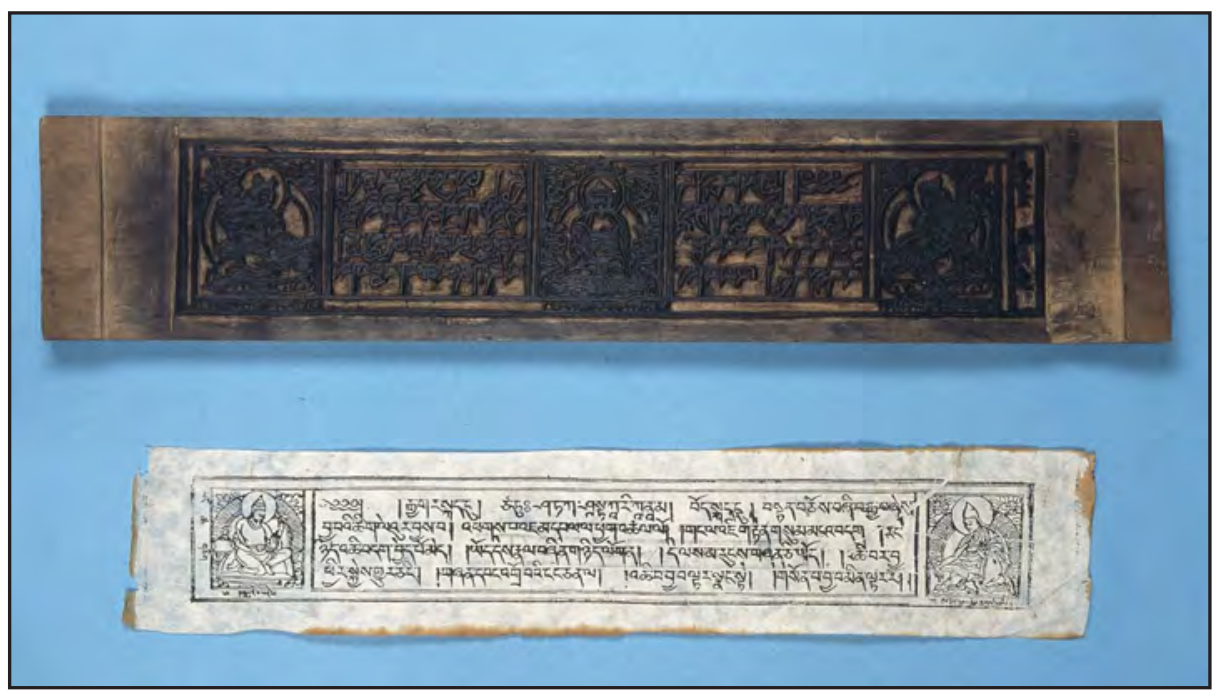

Fig. 8a. Øverst ses en tibetansk trykblok med titelblad til bind 106 af Tanjur-udgaven af de samlede buddhistiske skrifter Tripitaka. Skäret i midten af 1900-tallet. Nederst et bloktryk af den samme side dog fra en anden tidlig 1900-tals udgave (Det Kongelige Bibliotek).

serne havde opfundet bloktrykket en gang $\mathrm{i}$ 700-tallet, og da trykte tekster var mindre kostbare at producere end håndskrifter, overtog tibetanerne denne teknik. Dog bibeholdt man palmebladsformatet, således at tibetanske trykte bøger indtil 1800-tallet var i det traditionelle aflange tværformat. Teksten blev skåret i blokkene og anbragt på samme måde som i håndskrifterne, dog satte man gerne en ramme omkring teksten, ofte med to dobbeltstregede linier. Fra den tidlige del af 1900-talllet kan man i visse tilfælde se illustrationer lagt ind i selve teksten uden nogen form for afgrænsninger. Dette er helt tydeligt en inspiration, man har fået fra Vesten.

Det var almindeligt at beskytte teksterne med dækplader, der kunne være enkle stykker groft tilvirkede til fint forarbejdede og forgyldte træplader. En del af de dekorerede dækplader havde både dekorationer og illustrationer på den ydre og den indre side. De ydre sider kan være udsmykket med malede eller udskårne buddhafigurer mellem dyr, planter, buddhistisk symboler eller geometriske mønstre. Undertiden hvælvede den øverste dækplade udad - lidt som et tag på et tempel. Desuden kunne tekstdele og diverse mønstre være lagt i tommetykt farvede eller forgyldte lag, så de stod frem som relieffer. Indersiderne var som regel illustreret med buddhafigurer og/eller med fortællende scener fra især fra Buddhas liv. Nogle af de indre illustrationer var forsænket i dækpladen og beskyttet af et tekstilgardin ligesom det kan ses på nogle af de fint dekorere titelblade. Dette ses ofte i forbindelse med mongolsk inspirerede illustrationer. For at holde sammen på bladene og dækpladerne kunne man enten binde dem sammen med en læderstrop eller lægge dem i et svøb, som enten er ensfarvet eller indfarvet med mønstre af geometrisk art eller plantemønstre.

I dag ser man to tendenser i trykningen af tibetanske og bhutanske bøger. 


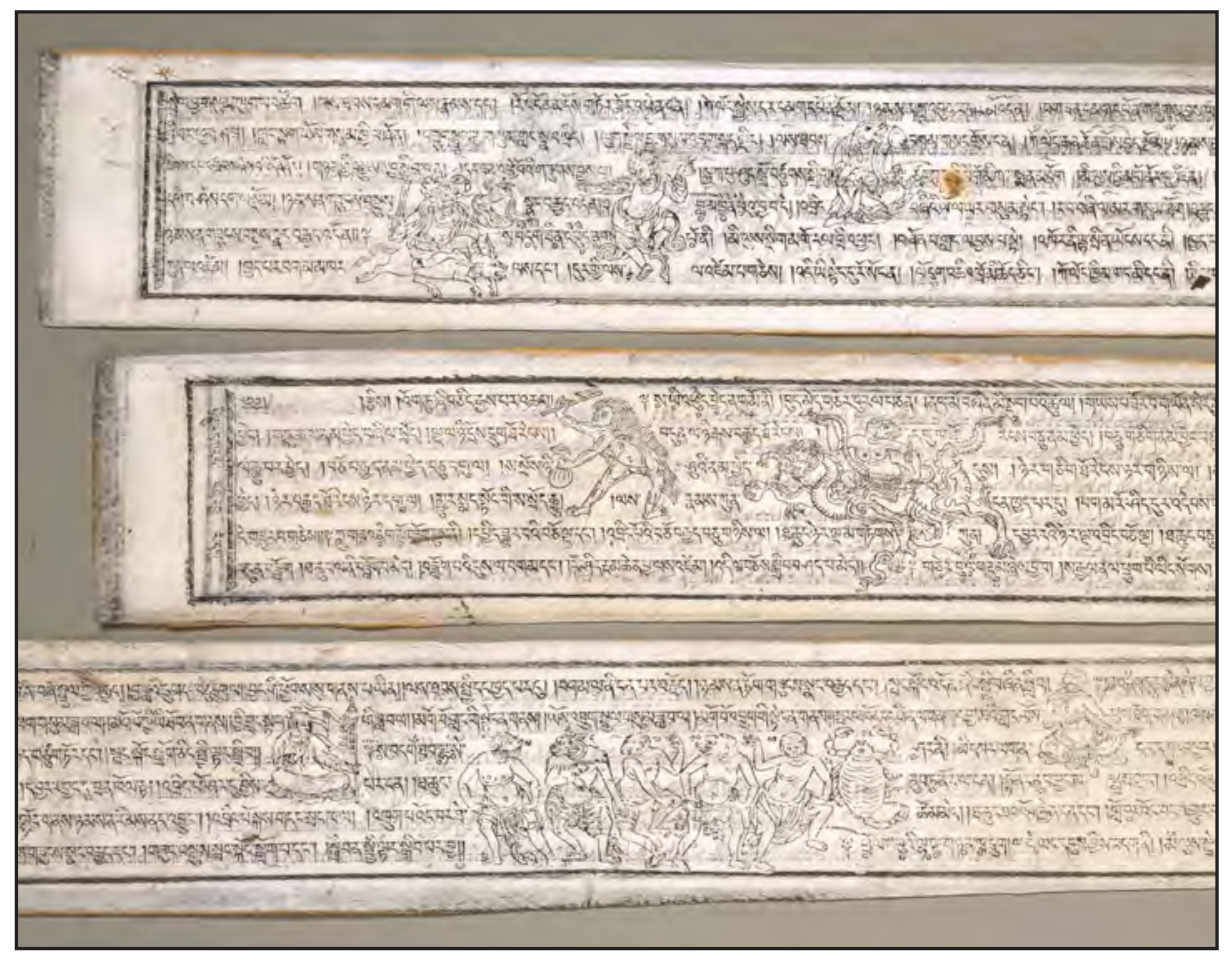

Fig. 8b. Tibetansk bloktryk med tekstintegrerede billeder fra Vaidûrya dkar po, (håndbog i astronomi, kalender beregninger, astrologi og spådomstagning), trykt i 1909 (Det Kongelige Bibliotek).

Hvis det drejer sig om traditionelle buddhistiske værker plejer man at trykke dem på lange papirark i det traditionelle tværformat, mens andre emner trykkes og indbindes $\mathrm{i}$ kodeksformatet som i Vesten. I Tibet ser man dog at kodeksformatet også benyttes til de traditionelle buddhistiske tekster.

\section{Mongoliet}

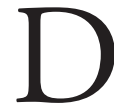

en mongolske bog udviklede sig først i forbindelse med etableringen af deres verdensrige i 1200 -tallet, hvor også mongolerne tog det uiguriske alfabet til sig. Mange mongoler blev stærkt draget mod den tibetanske udlægning af buddhismen, så de tog den lamaistiske buddhisme til sig og dermed også palmeblads- formatet i deres religiøse skrifter. Samtidig fik de også inspiration fra Nepal og Kina, hvilket dels medførte bøger i ret brede og korte palmebladsagtige former og dels den kinesiske hæftede bog, hvor bladene var syet eller bundet sammen. I den kinesiske bog foldede man papirark sammen på midten og skrev eller trykte på den ydre del. De beskrevne ark er tynde, og de blev lagt i rækkefølge oven på hinanden og hæftet sammen ved de åbne folder, et stykke fra kanterne, med tråde. Hvert ark har så tekst på den ydre del, men ingen tekst på den indre del, der ikke kan åbnes uden af man sprætter siden op. Papiret i en del af håndskrifterne er ret kraftigt og kan derfor ikke foldes som de tynde ark i den kinesiske bogform. Alligevel 


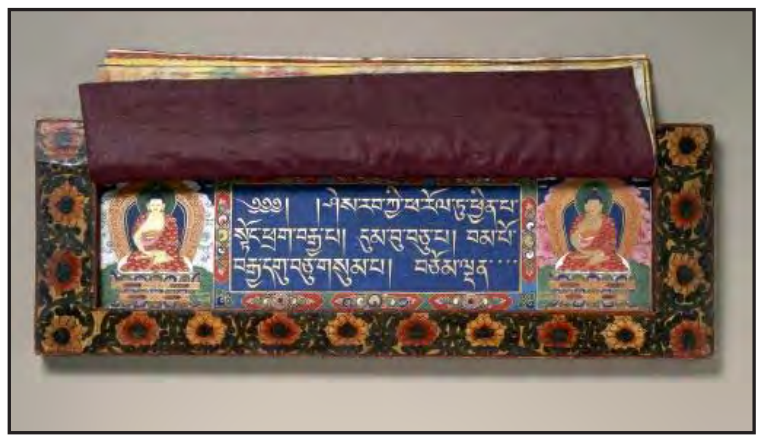

Fig. 9. Den dekorerede inderside af den tibetanske udgave af det buddhistiske værk Satasâharikâ prajnaparamitâ (om tombedens visdom) med flere lag af beskyttende gardiner. Kejserligt haindskrift fra 1700-tallet (Det Kongelige Bibliotek).

samles de gerne med snoede papirbånd langs ryggen, så bogen fremstår som en almindelig hæftet kinesisk bog.

Før papir var almindeligt i Mongoliet, anvendtes birkebark som skrive- materiale, men selv efter papiret kom $i$ anvendelse brugte man bark, da det nogle steder var lettere at erhverve end papir. Teksten blev skrevet i tusch med pensel, og den blev skrevet fra venstre mod højre i kolonner fra

Fig. 10. Tibetansk håndskrift liggende på indersiden af dets svøb. Svøbet er dekoreret med trykte geometrisk udformede plantemønstre. 1800-tallet (Det Kongelige Bibliotek).

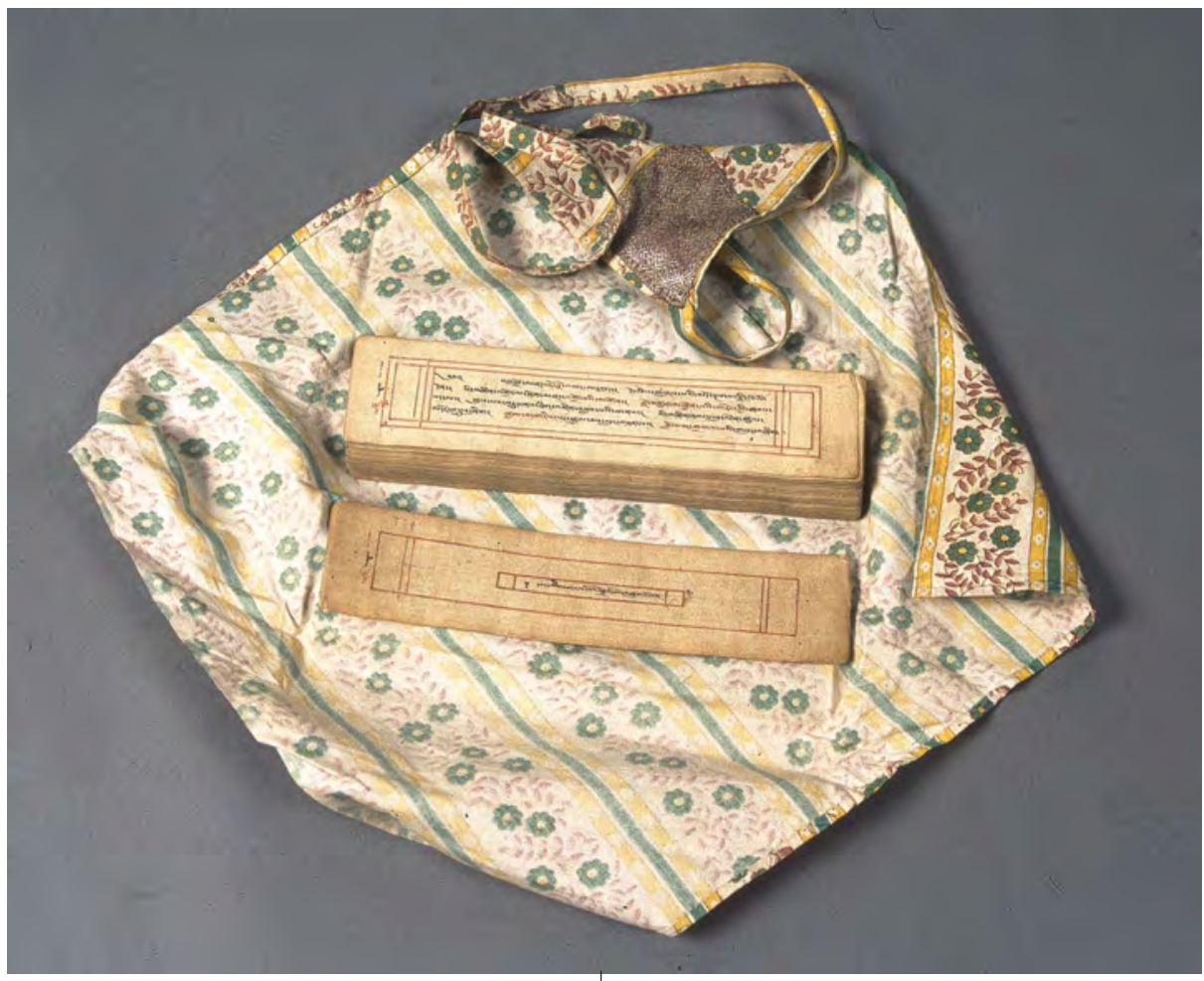




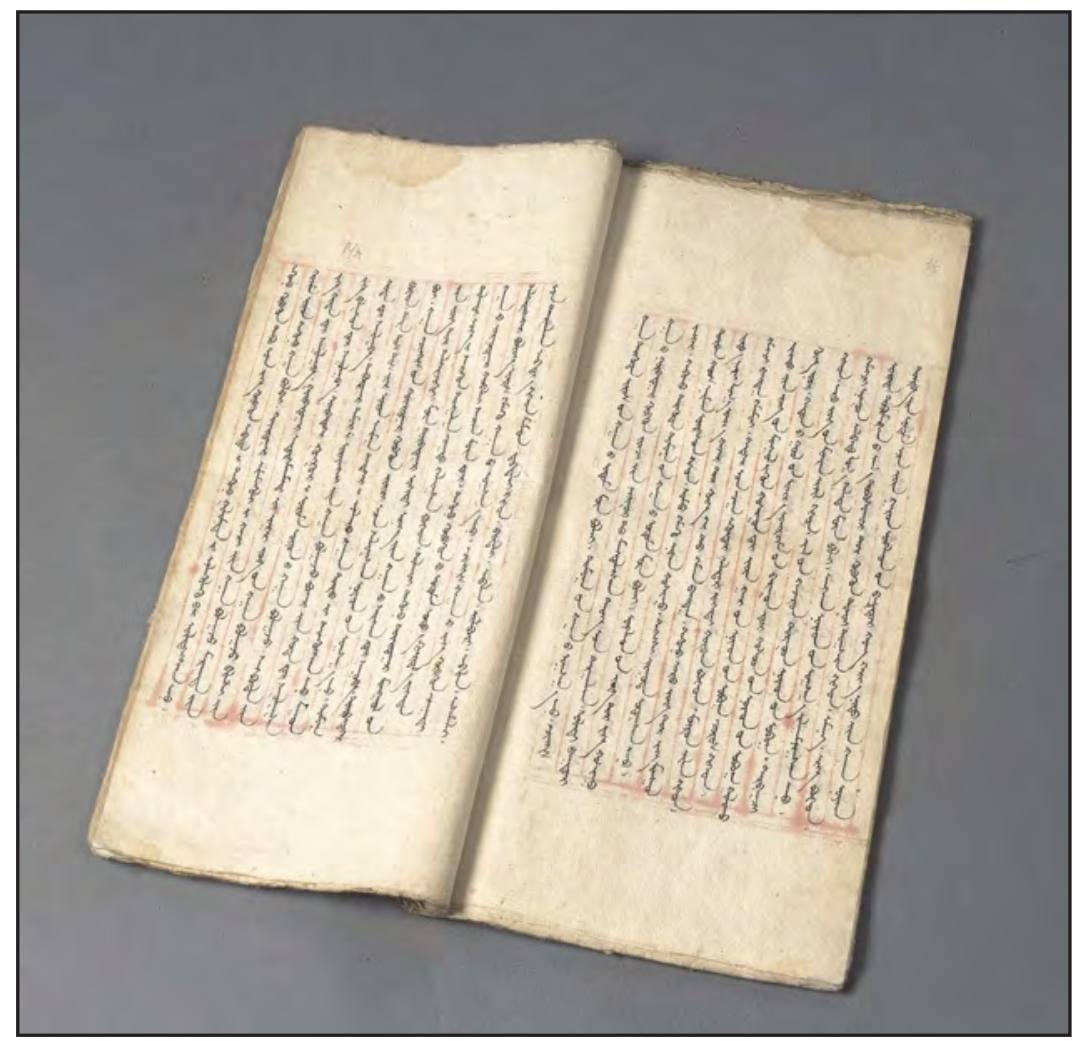

Fig. 11. Mongolsk håndskrift haftet som en kinesisk bog, Erdeni-yin erike (Mongolsk krønike om udbredelsen af buddhismen i Mongoliet i samhørighed med den kejserlige familie). Laseretning fra højre mod venstre og fra top til bund. Dateret til 1835 (Det Kongelige Bibliotek).

top til bund. Da mongolsk skrives i lodrette kolonner, medførte dette, at bøger i palmebladsformatet havde en tendens til at blive noget bredere end de tibetanske og bhutanske tværformater, hvor teksten blev skrevet i vandrette linier. Der kan ses en ramme om nogle af teksterne, og i den kinesiske bogform ser man undertiden kolonnerne markeret i sort eller rødt.

\section{Man ser både håndskrifter og} bloktrykte tekster, og håndskrifter er fremstillet helt op i det tidlige 1900-tal, formodentlig på grund af at der var så få trykkerier i det vidstrakte Mongoliet. Verdslige værker, ord- bøger og tosprogede lærebøger var tit hæftet som kinesiske bøger, hvor man undertiden kan se den enkle form for sammenbinding af papirarkene med sammenviklede papirstrimler, der er boret gennem alle arkene og fæstnet med en enkelt knude. I modsætning til de kinesiske bøger blev de mongolske bøger skrevet fra venstre mod højre, således at den mongolske hæftede bog åbnes ved at blade fra højre mod venstre ganske som i en vesterlandsk bog.

$$
\text { Formatet på håndskrifter er }
$$
mangeartet, lige fra tværformat på mellem $20 \times 6 \mathrm{~cm}$ og $52 \times 12 \mathrm{~cm}$ til næsten kvadra- 


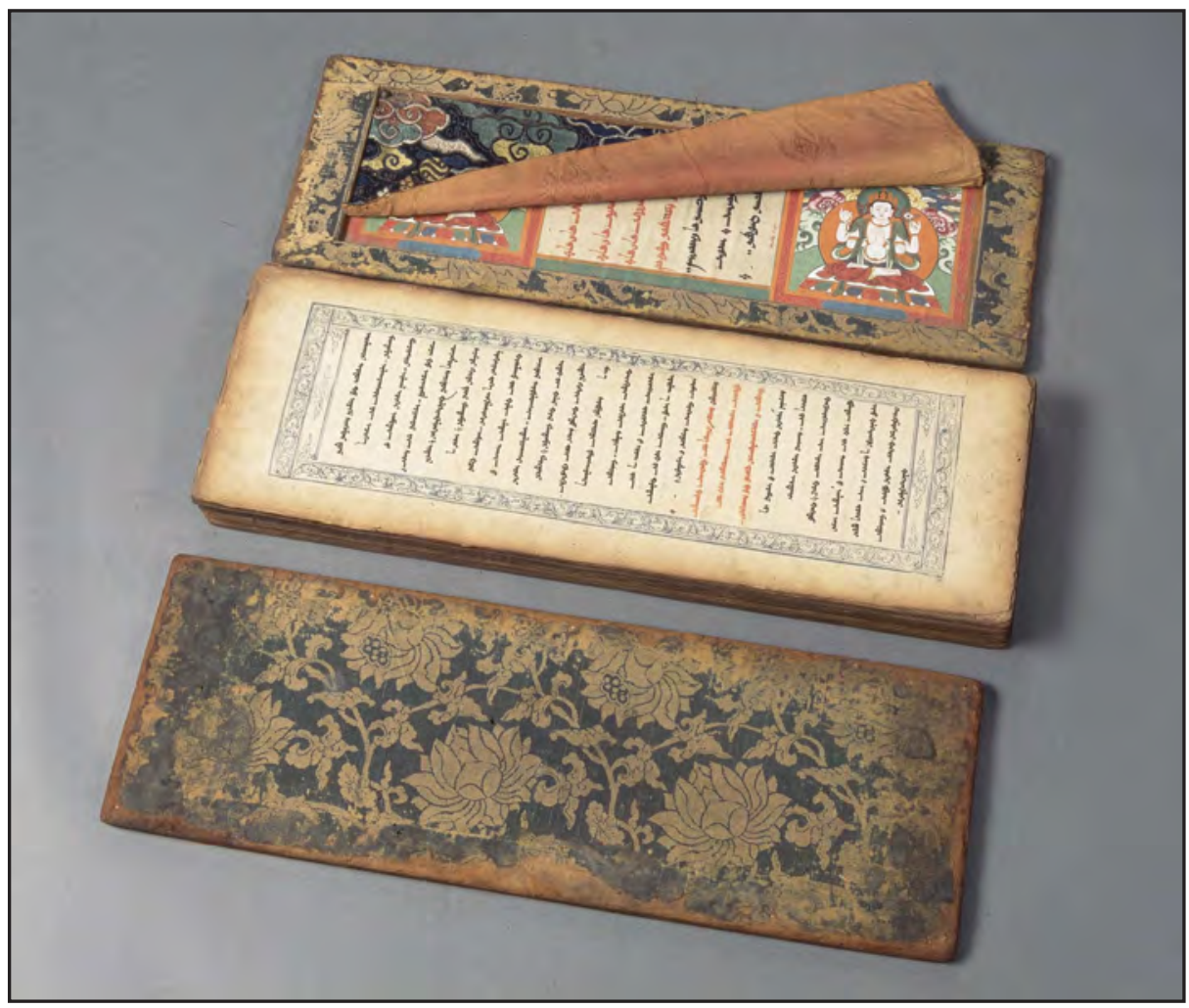

Fig. 12. Buddhistisk sutra på mongolsk om fuldstandiggørelsen af ens visdom (Astasahasrikâ). Dakpladerne er blevet bekladt med brokadetekstiler og titelblad og dekorationer er nedfaldet på indersiden af den øverste dakplade og er blevet beskyttet af et gardin. Håndskrift i rod og sort tusch fra 1800-tallet (Det Kongelige Bibliotek).

tiske på omkring $25 \times 25 \mathrm{~cm}$. De trykte værker er i tværformatet mellem 25 x 6 til 68 x $23 \mathrm{~cm}$ mens de hæftede bøger ligger mellem $12 \times 9$ til $45 \times 28 \mathrm{~cm}$.

Håndskrevne og trykte værker i palmebladsformatet blev oftest beskyttet af dækplader fremstillet i træ. Bøger i den kinesiske bogform fik enten forstærket de ydre blade med tekstiler eller med flere lag papir, eller de blev lagt i kinesiske bogkapsler eller æsker. Dækpladerne var på mange måder lig med de tibetanske og bhutanske. Dog kan man se en forkærlighed for træplader, der var beklædt men brokadestykker, der gik om på indersiden hen til den indsænkede illustration. Brokadernes mønstre var som regel plante- eller skymønstre. Mange af værkerne blev svøbt i klædestykker med fastsyede bændler. Undertiden var disse svøb fint udsmykket med farverige mønstrede tekstiler.

Illustrationer i teksten forekommer også, og de kunne være placeret i billedruder som de tibetanske buddhistiske værker eller være anbragt som helsides illustrationer. I pragtudgaver ser man forgyldte buddha-figurer omgivet af fine mangefarvede dekorationer anbragt for hver sektion af en tekst. Illustrationerne i håndskrifterne var som regel 


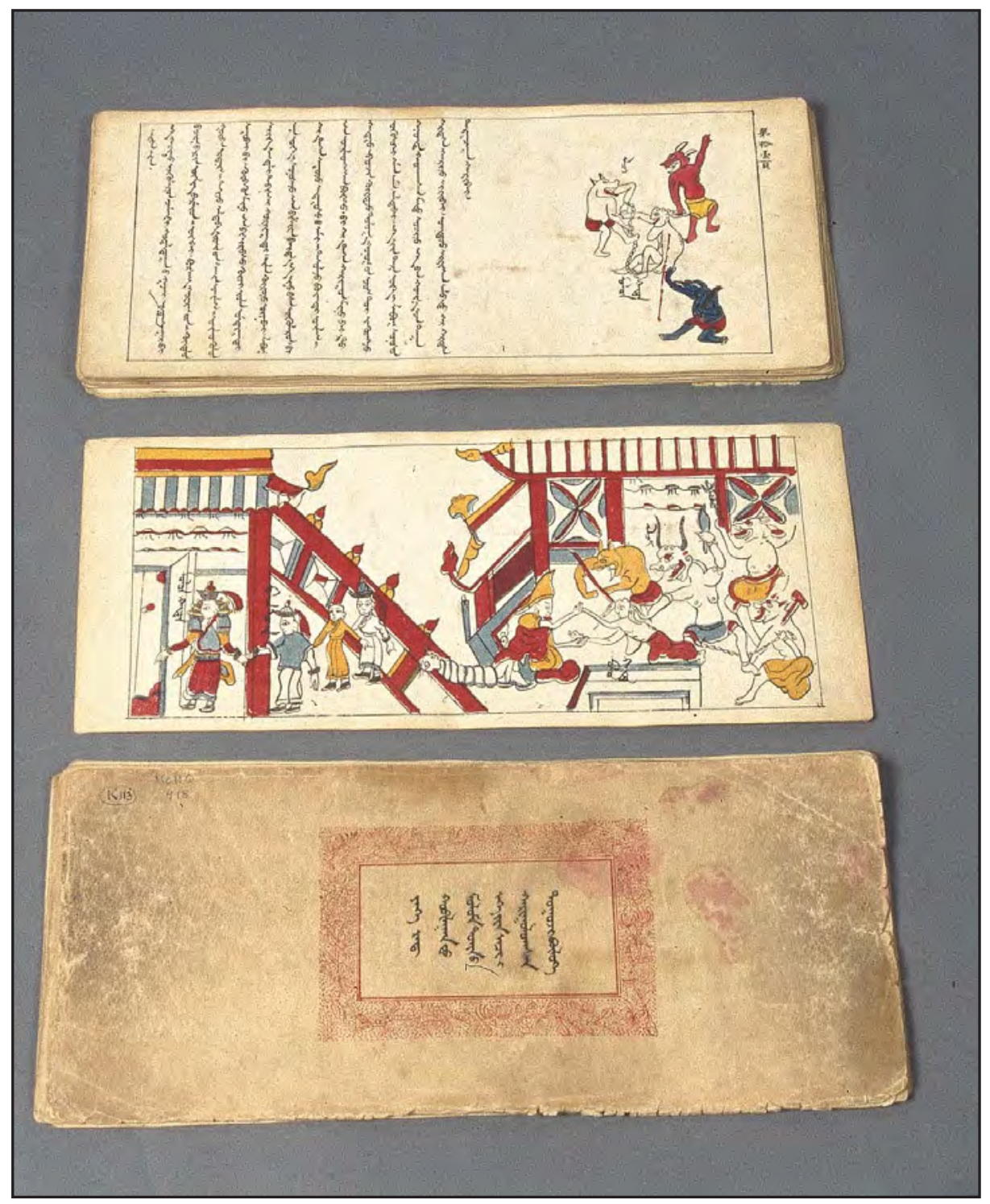

Fig. 13. Mongolsk litografi fra sent i 1800-tallet af de otte varme og de otte kolde helveder (Maudgalyâyana-legenden). Beretning om den fromme munk, Molon toyins, rejse $i$ helvedet for at befri sin moder for pinsler (Det Kongelige Bibliotek).

fint udførte med mange farver. De fleste eksempler er buddhistiske figurer og billeder, der relaterer sig til opbyggelige fortællinger.
På de trykte bøger er titelblad og forord gerne trykt i rødt og undertiden udsmykket med buddhistiske figurer for en- 


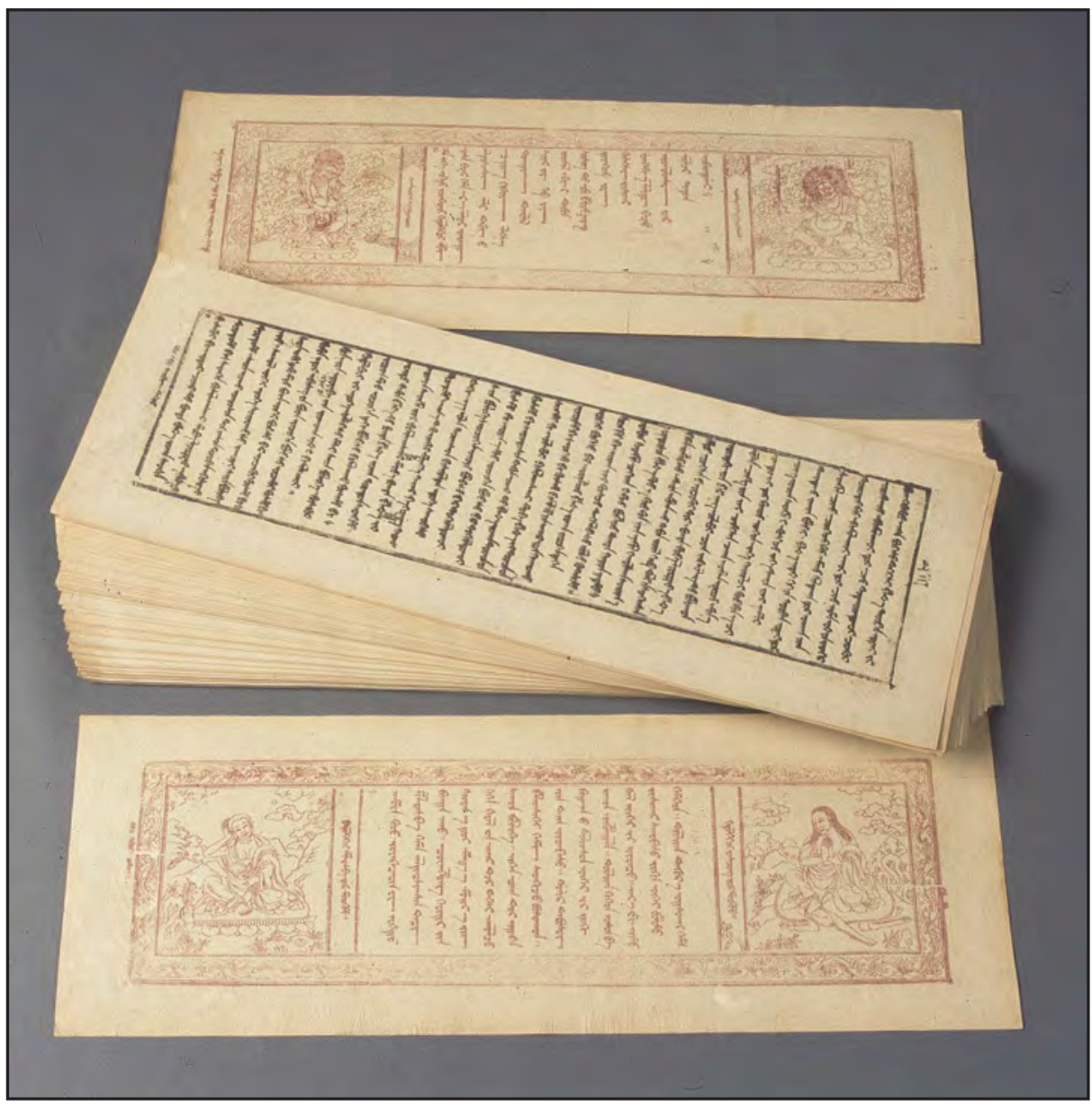

Fig. 14. Buddhistisk mongolsk bloktryk fra 1756 (om den hellige tibetanske helgen Milaraspa) hvor forste og sidste del er tryk i rødt, mens selve teksten for hovedpartens vedkommende er trykt i sort (Det Kongelige Bibliotek).

den af bladarkene. I den del af de trykte buddhistiske værker ser man en række af guder og vogtere på det sidste blad i stablen også trykt i rødt.

Mongolske bøger i dag er trykt og hæftet efter vestlig model. En del af de moderne bøger er trykt i translittereret form med det kyrilliske alfabet efter indflydelse fra Sovjet. I disse bøger ser man teksten skrevet i linier fra venstre mod højre under hinanden som i vestlige bøger. Bøger trykt med det mongolske alfabet har normalt teksten sat i de traditionelle lodrette kolonner, hvor man læser teksten fra venstre mod højre. 